\title{
Effect of Garlic Oil and Four of its Compounds on Rumen Microbial Fermentation
}

\author{
M. Busquet, ${ }^{1}$ S. Calsamiglia, ${ }^{1}$ A. Ferret, ${ }^{1}$ M. D. Carro, ${ }^{2}$ and C. Kamel ${ }^{3}$ \\ ${ }^{1}$ Departament de Ciència Animal i dels Aliments, Universitat Autònoma de Barcelona, \\ 08193 Bellaterra, Spain \\ ${ }^{2}$ Departamento de Producción Animal I, Universidad de León, 24071 León, Spain \\ ${ }^{3}$ Pancosma, 01205 Bellegarde-sur-Valserine Cedex, France
}

\begin{abstract}
Different concentrations $(3,30,300$, and $3000 \mathrm{mg} / \mathrm{L}$ of culture fluid) of garlic oil (GAR), diallyl sulfide (DAS), diallyl disulfide (DAD), allicin (ALL), and allyl mercap$\tan$ (ALM) were incubated for $24 \mathrm{~h}$ in diluted ruminal fluid with a 50:50 forage:concentrate diet (17.7\% crude protein; $30.7 \%$ neutral detergent fiber) to evaluate their effects on rumen microbial fermentation. Garlic oil (30 and $300 \mathrm{mg} / \mathrm{L}$ ), DAD (30 and $300 \mathrm{mg} / \mathrm{L}$ ), and ALM (300 $\mathrm{mg} / \mathrm{L}$ ) resulted in lower molar proportion of acetate and higher proportions of propionate and butyrate. In contrast, at $300 \mathrm{mg} / \mathrm{L}$, DAS only increased the proportion of butyrate, and ALL had no effects on volatile fatty acid proportions. In a dual-flow continuous culture of rumen fluid fed the same 50:50 forage:concentrate diet, addition of GAR (312 mg/L), DAD (31.2 and $312 \mathrm{mg} /$ $\mathrm{L})$, and ALM (31.2 and $312 \mathrm{mg} / \mathrm{L}$ ) resulted in similar changes to those observed in batch culture, with the exception of the lack of effect of DAD on the proportion of propionate. In a third in vitro study, the potential of GAR $(300 \mathrm{mg} / \mathrm{L}), \mathrm{DAD}(300 \mathrm{mg} / \mathrm{L})$, and ALM $(300 \mathrm{mg} /$ L) to decrease methane production was evaluated. Treatments GAR, DAD, and ALM resulted in a decrease in methane production of $73.6,68.5$, and $19.5 \%$, respectively, compared with the control. These results confirm the ability of GAR, DAD, and ALM to decrease methane production, which may help to improve the efficiency of energy use in the rumen.
\end{abstract}

(Key words: rumen fermentation, garlic oil, diallyl disulfide, allyl mercaptan)

Abbreviation key: ALL = allicin, ALM = allyl mercaptan, DAS = diallyl sulfide, DAD = diallyl disulfide, GAR = garlic oil, HMG-CoA = 3-hydroxy-3-methylglutaryl coenzyme A, LPep = large peptide, LOV = lovastatin, $\mathbf{M O N}=$ monensin, $\mathbf{S P e p}+\mathbf{A A}=$ small pep-

Received March 17, 2005.

Accepted July 18, 2005.

Corresponding author: Sergio Calsamiglia; e-mail: sergio. calsamiglia@uab.es. tide plus amino acid, TCA-N = TCA-soluble N, TA-N = tungstic acid-soluble $\mathrm{N}$.

\section{INTRODUCTION}

A goal of ruminant microbiologists and nutritionists is to manipulate the ruminal microbial ecosystems to improve the efficiency of converting feed to animal products consumable by humans. The use of feed additives such as antibiotics has proven to be a useful tool to reduce energy (in the form of methane) and nitrogen (in the form of ammonia) losses from the diet (Schelling, 1984). However, scientists have recently become interested in evaluating alternatives for manipulating the gastrointestinal microflora in livestock due to the increasing public concern about the use of antibiotics in the animal feed industry. Plant extracts have been used for centuries for various purposes (e.g., traditional medicine, industrial applications, food preservatives) due to their antimicrobial properties (Davidson and Naidu, 2000) and because most of them are categorized as GRAS (Generally Recognized as Safe) for human consumption (FDA, 2004). The use of plant extracts appears to be one of the most natural alternatives to the antibiotic use in animal nutrition.

Garlic oil is produced commercially by heating crushed garlic (Allium sativa) cloves to $100^{\circ} \mathrm{C}$ and collecting the vapor as a distillate. Garlic oil has been shown to exhibit a wide spectrum of antibacterial activity against gram-negative and gram-positive bacteria (Reuter et al., 1996). In a previous study in a continuous culture system, $300 \mathrm{mg} / \mathrm{L}$ of garlic oil reduced the proportions of acetate and branched-chain VFA, and increased the proportions of propionate and butyrate and the small peptide plus amino acid N (SPep+AA N) concentration (Busquet et al., 2005). These changes in the fermentation profile are consistent with those observed with methane inhibitors (Martin and Macy, 1985) and have the potential to beneficially modify rumen microbial fermentation. However, garlic oil is a complex mixture of many secondary plant products including allicin $\left(\mathrm{C}_{6} \mathrm{H}_{10} \mathrm{~S}_{2} \mathrm{O}\right)$, diallyl sulfide $\left(\mathrm{C}_{6} \mathrm{H}_{10} \mathrm{~S}\right)$, dial- 
lyl disulfide $\left(\mathrm{C}_{6} \mathrm{H}_{10} \mathrm{~S}_{2}\right)$, and allyl mercaptan $\left(\mathrm{C}_{3} \mathrm{H}_{6} \mathrm{~S}\right)$, among others (Lawson, 1996), which makes difficult to elucidate the precise mechanism of action on rumen microbial fermentation and its use as a feed additive.

The aim of the present study was to evaluate the effects of some compounds found in garlic oil on rumen microbial fermentation patterns to determine if one of these compounds could be the main factor responsible for the effects of garlic oil, or if, on the contrary, the results observed with garlic oil are due to different interactions between its compounds.

\section{MATERIALS AND METHODS}

The present study was divided into 3 experiments. The first experiment consisted of a short-term in vitro batch fermentation trial with different doses of garlic oil, diallyl disulfide (30.8\% of garlic oil), diallyl sulfide (10.6\% of garlic oil), allicin (0.7\% of garlic oil), and allyl mercaptan (a common metabolite derived from garlic oil). In the second experiment, those compounds with similar effects (in the first experiment) to garlic oil were selected for their in vitro evaluation in continuous culture. A third trial in batch cultures was conducted to confirm the hypothesis of the ability of garlic oil and its selected active components to decrease methane production.

\section{In Vitro Batch Fermentation Trial}

The effects of different concentrations of garlic oil and some of its compounds were evaluated using an in vitro batch culture of rumen fluid supplied with a 50:50 forage:concentrate diet $(17.7 \% \mathrm{CP}, 30.7 \% \mathrm{NDF}$, and 19.7\% ADF, DM basis). The diet (DM basis) consisted of alfalfa hay (49.4\%), ground barley grain (24.0\%), ground corn grain $(15.4 \%)$, soybean meal $(9.7 \%)$, white salt $(\mathrm{NaCl}, 0.3 \%)$, monobasic sodium phosphate $\left(\mathrm{H}_{2} \mathrm{Na}\right.$ $\mathrm{PO}_{4} \cdot 2 \mathrm{H}_{2} \mathrm{O}, 0.4 \%$ ), and a vitamin and mineral mixture (0.4\%; contained per kg: $7 \mathrm{mg} \mathrm{Co}, 167 \mathrm{mg} \mathrm{Cu}, 33 \mathrm{mg} \mathrm{I}$, 2,660 mg Mn, $27 \mathrm{mg} \mathrm{Se}$, and 4,660 mg Zn; $1000 \mathrm{kIU}$ of vitamin A, $200 \mathrm{kIU}$ of vitamin $\mathrm{D}_{3}$, and $1330 \mathrm{mg}$ of vitamin $\mathrm{E} ; 2.67 \mathrm{~g}$ of urea, $67 \mathrm{~g}$ of $\mathrm{NaCl}, 33 \mathrm{~g}$ of sulfur, and $300 \mathrm{~g}$ of $\mathrm{MgO}$ ). The diet was designed to meet or exceed nutrient recommendations for a Holstein cow (650 kg BW) producing $30 \mathrm{~kg}$ of milk (NRC, 2001). Treatments were: control (no additive), garlic oil (GAR, Allium sativa, standardized at $0.7 \%$ of allicin), diallyl sulfide (DAS; $\mathrm{C}_{6} \mathrm{H}_{10} \mathrm{~S}$, purity of $95 \%$ ), diallyl disulfide (DAD; $\mathrm{C}_{6} \mathrm{H}_{10} \mathrm{~S}_{2}$, purity of 95\%), allyl mercaptan (ALM; $\mathrm{C}_{3} \mathrm{H}_{6} \mathrm{~S}$, purity of $85 \%$ ), and allicin $\left(\mathbf{A L L} ; \mathrm{C}_{6} \mathrm{H}_{10} \mathrm{~S}_{2} \mathrm{O}\right.$, purity of 98\%). Plant extracts were provided by Pancomsa SA (Bellegarde-sur-Valserine Cedex, France). Four concentrations were used for each compound: 3, 30, 300, and $3000 \mathrm{mg} / \mathrm{L}$ of the total culture fluid. Compounds were tested in triplicate at each dose, and fermentations were repeated on 2 separate days. Ruminal fluid was obtained from 2 rumen-fistulated lactating dairy cows fed a 50:50 forage:concentrate diet. The diet (DM basis) consisted of alfalfa hay (34.9\%), ryegrass hay (14.8\%), ground barley grain $(11.4 \%)$, ground corn grain (11.4\%), soybean meal $(1.6 \%)$, cottonseed $(7.9 \%)$, corn gluten feed $(11.6 \%)$, molasses $(3.2 \%)$, calcium soaps of fatty acids (1.3\%), and a mineral and vitamin mix (2.1\%). Rumen fluid of each cow was mixed and strained through 4 layers of cheesecloth, mixed in a 1:1 proportion with a phosphate-bicarbonate buffer (McDougall, 1948), purged with anaerobic-grade $\mathrm{CO}_{2}(<2 \mathrm{ppm} \mathrm{O})_{2}$, and standardized at $\mathrm{pH} 7.0 \pm 0.1$ with $3 \mathrm{~N} \mathrm{HCl}$. The fermentation process was conducted in $90-\mathrm{mL}$ polypropylene tubes containing $50 \mathrm{~mL}$ of culture fluid with 0.5 $\mathrm{g}$ of the diet ground through a $1-\mathrm{mm}$ mesh screen. A total of 10 and $100 \mathrm{mg}$ of all compounds were dissolved in $10 \mathrm{~mL}$ of ethanol, and $0.15 \mathrm{~mL}$ of each stock solution was added into the tubes to achieve a final concentration of 3 and $30 \mathrm{mg} / \mathrm{L}$, respectively. A total of 15 and $150 \mathrm{mg}$ of all compounds were supplied directly into the tubes to achieve a final concentration of 300 and $3000 \mathrm{mg} / \mathrm{L}$, respectively. The control and the concentrations of 300 and $3000 \mathrm{mg} / \mathrm{L}$ of each compound were also dosed with the equivalent amount of ethanol $(0.15 \mathrm{~mL})$. Tubes were purged with anaerobic-grade $\mathrm{CO}_{2}(<2 \mathrm{ppm}$ $\mathrm{O}_{2}$ ) before being sealed with rubber stoppers fitted with pressure release valves. Incubations were conducted at $39^{\circ} \mathrm{C}$ in a shaking waterbath. After $24 \mathrm{~h}$, the $\mathrm{pH}$ of the culture fluid was measured immediately with a $\mathrm{pH}$ meter and samples for ammonia N and VFA were collected for analysis.

\section{In Vitro Continuous Culture Trial}

Eight 1320-mL dual-flow continuous culture fermentors (Hoover et al., 1976) were used in 3 replicated periods of $8 \mathrm{~d}$. On the first day of each period, all fermentors were inoculated with ruminal fluid obtained from 2 rumen-fistulated lactating dairy cows fed the same 50:50 forage:concentrate diet as cows in the batch fermentation trial. Fermentors were fed $95 \mathrm{~g}$ of DM/ $\mathrm{d}$ in 3 equal portions (every $8 \mathrm{~h}$ ) of the same 50:50 forage:concentrate diet used in the batch fermentation trial. Temperature $\left(38.5^{\circ} \mathrm{C}\right), \mathrm{pH}(6.4 \pm 0.05)$, and liquid $(10 \% / \mathrm{h})$ and solid $(5 \% / \mathrm{h})$ dilution rates were maintained constant and monitored using a personal computer and the LabView Software (FieldPoint, National Instruments, Austin, TX). Anaerobic conditions were maintained by infusion of $\mathrm{N}_{2}$ at a rate of $40 \mathrm{~mL} / \mathrm{min}$. Artificial saliva (Weller and Pilgrim, 1974) was continuously infused into flasks, and contained $0.4 \mathrm{~g} / \mathrm{L}$ of urea to simu- 
late recycled N. Treatments were: control (no additive), an average concentration of $312 \mathrm{mg} / \mathrm{L}$ of culture fluid of GAR (GAR300, positive control), average concentrations of 31.2 and $312 \mathrm{mg} / \mathrm{L}$ of culture fluid of DAD (DAD30 and DAD300, respectively), and average concentrations of 31.2 and $312 \mathrm{mg} / \mathrm{L}$ of culture fluid of ALM (ALM30 and ALM300, respectively). On the first day of each period, $48.6 \mathrm{mg}$ each of DAD and ALM and 486 $\mathrm{mg}$ of all compounds were added as a single dose into each fermentor 1 min before the first fermentor's feeding. This addition provided an initial concentration of the compounds of 36.8 and $368 \mathrm{mg} / \mathrm{L}$ of culture fluid, respectively. The daily dose of DAD30 and ALM30 was dissolved in ethanol at a 1:10 ratio. All additives were stored at $5^{\circ} \mathrm{C}$ in a smoked glass flask. The daily dose of the additives was divided into 3 fractions and dosed into the fermentors $1 \mathrm{~min}$ before each feeding to achieve the expected concentrations. The control, GAR300, DAD300, and ALM300 fermentors were also dosed with the equivalent amount of ethanol ( $0.33 \mathrm{~mL}$ per feeding).

Each experimental period consisted of $8 \mathrm{~d}$ ( $5 \mathrm{~d}$ for adaptation and $3 \mathrm{~d}$ for sample collection). During the $8 \mathrm{~d}$ of each period, $8 \mathrm{~mL}$ of filtered fermentor fluid was taken $2 \mathrm{~h}$ after the morning feeding to determine VFA and ammonia $\mathrm{N}$ concentration, to study the adaptation process of the microorganisms to the presence of the additives. During the last $3 \mathrm{~d}$ of each period, $40 \mathrm{~mL}$ of filtered fermentor fluid were taken at $0,2,4$, and $6 \mathrm{~h}$ after the morning feeding to determine tungstic acidsoluble N (TA-N), TCA-soluble N (TCA-N), and ammonia $\mathrm{N}$.

During sampling days, collection vessels were maintained at $4^{\circ} \mathrm{C}$ to impede microbial action. Solid and liquid effluents were mixed and homogenized for $1 \mathrm{~min}$, and a 500-mL sample was removed via aspiration. Upon completion of each period, effluents from the 3 sampling days was composited and mixed within fermentor, and homogenized for $1 \mathrm{~min}$. Subsamples were taken for the determination of total N, ammonia N, and VFA concentration, and the remaining sample was lyophilized. Lyophilized dry samples were analyzed for DM, ash, NDF, $\mathrm{ADF}$, and purine contents.

Bacteria were obtained from the fermentor flasks on the last day of each experimental period. Solid- and liquid-associated bacteria were isolated using a combination of several detachment procedures (Whitehouse et al., 1994) selected to obtain the maximum detachment without affecting cell integrity. One hundred milliliters of a $0.2 \%$ methylcellulose solution with marbles [2 $(\mathrm{n}=30)$ and $4(\mathrm{n}=15) \mathrm{mm}$ diameter] was added to each fermentor, and incubation continued in the same fermentor flasks at $39^{\circ} \mathrm{C}$ for $1 \mathrm{~h}$ to remove attached bacteria (Minato and Suto, 1978). After the incubation, fermentor flasks were refrigerated for $24 \mathrm{~h}$ at $4^{\circ} \mathrm{C}$. After this incubation, fermentor contents were agitated for $1 \mathrm{~h}$ to dislodge loosely attached bacteria. Finally, the fermentor contents were filtered through cheesecloth and washed with saline solution. Bacterial cells were isolated by differential centrifugation at $1000 \times g$ for 15 min to separate feed particles, and the supernatant was centrifuged at $25,000 \times g$ for $20 \mathrm{~min}$ to isolate the bacterial cells. Pellets were rinsed twice with saline solution and recentrifuged at $25,000 \times g$ for $25 \mathrm{~min}$. The pellet was recovered with distilled water to prevent contamination of bacteria with ash. Bacterial cells were lyophilized and analyzed for DM, ash, N, and purine contents. Digestion of DM, OM, NDF, ADF, and CP and flows of total N, NAN, bacterial N, and dietary N were calculated as described by Stern and Hoover (1990).

\section{In Vitro Gas Production Trial}

The same 50:50 forage:concentrate diet used in previous trials and ground through a 1-mm screen was fermented in vitro with buffered rumen fluid. Treatments were: control (no additive), $300 \mathrm{mg} / \mathrm{L}$ of garlic oil (GAR300), $300 \mathrm{mg} / \mathrm{L}$ of diallyl disulfide (DAD300), 300 $\mathrm{mg} / \mathrm{L}$ of allyl mercaptan (ALM300), $12.5 \mathrm{mg} / \mathrm{L}$ of monen$\sin$ (MON; Sigma Chemical, St Louis, MO) and $5 \mathrm{mg} /$ L of lovastatin (LOV; Sigma Chemical) as positive controls. Ruminal fluid was obtained from 4 rumen-fistulated Merino sheep fed alfalfa hay (16\% CP and $47 \%$ NDF, DM basis) ad libitum and $400 \mathrm{~g}$ of concentrate (19\% CP and 16\% NDF, DM basis) per day administered in 2 equal portions at 0900 and $1800 \mathrm{~h}$. The concentrate was based on barley, corn, soybean meal, and a commercial vitamin-mineral mixture $(38,38,20$, and $2 \%$, respectively, DM basis). Rumen contents of each sheep were mixed and strained through 4 layers of cheesecloth into an individual Erlenmeyer flask with an $\mathrm{O}_{2}$-free headspace. Particle-free fluid was mixed with the buffer solution of Goering and Van Soest (1970; no trypticase added) in a $1: 4$ proportion at $39^{\circ} \mathrm{C}$, under continuous flushing with $\mathrm{CO}_{2}$, and $\mathrm{pH}=7.0$. Serum bottles $(120$ $\mathrm{mL}$ ) were prewarmed at $39^{\circ} \mathrm{C}$ and filled with $50 \mathrm{~mL}$ of diluted rumen fluid with $0.5 \mathrm{~g}$ of the diet. Lovastatin $(20.8 \mathrm{mg})$ and monensin $(52.1 \mathrm{mg})$ were dissolved in 5 $\mathrm{mL}$ of ethanol, and $0.06 \mathrm{~mL}$ of each stock solution was added into each bottle to achieve a final concentration of 5 and $12.5 \mathrm{mg} / \mathrm{L}$ of culture fluid (LOV and MON, respectively). A total of $15 \mathrm{mg}$ of GAR, DAD, and ALM were supplied directly into the bottles to achieve a final concentration of $300 \mathrm{mg} / \mathrm{L}$ of culture fluid (GAR300, DAD300, and ALM300, respectively). The control, GAR300, DAD300, and ALM300 bottles were also dosed with the equivalent amount of ethanol $(0.06 \mathrm{~mL})$. Bottles were sealed with rubber stoppers and aluminum caps and incubated at $39^{\circ} \mathrm{C}$. 
One bottle per treatment was incubated in each run and the experiment was repeated 4 times. After $8.5 \mathrm{~h}$ of incubation, total gas production was measured using a pressure transducer, and a gas sample was removed from each bottle and stored in a hemoguard Vacutainer before analysis for $\mathrm{CH}_{4}$ concentration. Bottles were withdrawn from the incubator $17 \mathrm{~h}$ after inoculation (corresponding to a passage rate of $0.06 \mathrm{per} h$ ) and total gas production was measured, and a gas sample was taken for $\mathrm{CH}_{4}$ analysis as described previously. Bottles were uncapped, the $\mathrm{pH}$ was measured immediately with a $\mathrm{pH}$ meter, and the fermentation was stopped by swirling the bottles on ice. Four milliliters from each bottle was taken to determine VFA and ammonia N concentration. Finally, the contents of the bottles were transferred to previously weighed filter crucibles. The residue of incubation was washed with $50 \mathrm{~mL}$ of hot $\left(50^{\circ} \mathrm{C}\right)$ distilled water, dried at $60^{\circ} \mathrm{C}$ for $48 \mathrm{~h}$, weighed, and analyzed for NDF and $\mathrm{ADF}$ content.

\section{Chemical Analyses}

Samples for VFA were prepared by a modified method from that described by Jouany (1982). One milliliter of solution made up of a $0.2 \%(\mathrm{wt} / \mathrm{wt})$ solution of mercuric chloride, $0.2 \%$ (wt/wt) of 4-methylvaleric acid as an internal standard, and $2 \%$ (vol/vol) orthophosphoric acid, was added to $4 \mathrm{~mL}$ of filtered culture fluid and frozen. In the gas production trial, $0.3 \mathrm{~mL}$ of the same solution was added to $1.2 \mathrm{~mL}$ of culture fluid and frozen. Samples were centrifuged at $3000 \times g$ for $30 \mathrm{~min}$, and the supernatant was analyzed by gas chromatography (model 6890; Hewlett Packard, Palo Alto, CA) using a polyethylene glycol nitroterephtalic acid-treated capillary column (BP21, SGE, Europe Ltd., Buckinghamshire, UK). The amounts of VFA produced in the 17-h in vitro gas production trial were obtained by subtracting the amounts present initially in the incubation medium from those determined at the end of the incubation period.

For ammonia $\mathrm{N}$ determination, a 4-mL sample of filtered cultured fluid was acidified with $4 \mathrm{~mL}$ of $0.2 \mathrm{~N}$ $\mathrm{HCl}$ and frozen. In the gas production trial, a $1.2-\mathrm{mL}$ sample of culture fluid was acidified with $1.2 \mathrm{~mL}$ of 0.2 $N \mathrm{HCl}$, and frozen. Samples were centrifuged at 25,000 $\times g$ for $20 \mathrm{~min}$, and the supernatant was analyzed by spectrophotometry (UV-120-01, Shimadzu, Kyoto, Japan) for ammonia N (Chaney and Marbach, 1962).

The TCA-N and TA-N were determined as described by Winter et al. (1964). A 16-mL sample of filtered fermentor fluid was added to $4 \mathrm{~mL}$ of $10 \%$ (wt/vol) sodium tungstate and $4 \mathrm{~mL}$ of $1.07 \mathrm{~N}$ sulfuric acid. Tubes were allowed to stand at $5^{\circ} \mathrm{C}$ for $4 \mathrm{~h}$, and then centrifuged at $9000 \times g$ for $15 \mathrm{~min}$. The supernatant was frozen until analyzed for TA-N by the Kjeldahl procedure (AOAC, 1990). To determine TCA-N, $4 \mathrm{~mL}$ of $50 \%$ (wt/vol) TCA solution was added to $16 \mathrm{~mL}$ of filtered fermentor fluid. After $4 \mathrm{~h}$ at $5^{\circ} \mathrm{C}$, tubes were centrifuged at $9000 \times g$ for $15 \mathrm{~min}$. The supernatant was frozen until analyzed for TCA-N by the Kjeldahl procedure. Based on the statements indicated by Licitra et al. (1996), results were used to calculate 1) large peptide $\mathrm{N}($ LPep N; between 3 and $10 \mathrm{AA})=[\mathrm{TCA}-\mathrm{N}]-[\mathrm{TA}-$ $\mathrm{N}$; and 2) small peptide (between 2 and $3 \mathrm{AA}$ ) plus amino $\operatorname{acid} \mathrm{N}(\mathrm{SPep}+\mathrm{AA} \mathrm{N})=[\mathrm{TA}-\mathrm{N}]-[\operatorname{ammonia} \mathrm{N}]$ (in $\mathrm{mg} / 100 \mathrm{~mL}$ ).

Effluent DM from fermentors was calculated by lyophilizing 200-mL aliquots in triplicate. Dry matter content of diet and bacterial samples were determined by drying samples for $24 \mathrm{~h}$ in a $103^{\circ} \mathrm{C}$ forced-air oven. Dry samples of diet, lyophilized effluents, and bacteria were ashed overnight at $550^{\circ} \mathrm{C}$ in a muffle furnace. Diet, effluents, and bacterial OM were determined by difference.

Total $\mathrm{N}$ of diet, effluents, and bacterial samples was determined by the Kjeldahl method (AOAC 1990). Sample $\mathrm{CP}$ was calculated as $\mathrm{N} \times 6.25$. Effluent $\mathrm{N}$ was determined in liquid samples.

The NDF and ADF content of diet, effluents, and incubation residues of the gas production trial were analyzed by the detergent system, using the sequential procedure of Van Soest et al. (1991), with sodium sulfite, a thermostable amylase, and corrected for ashes. Samples of lyophilized effluent and bacterial cells were analyzed for purine content (adenine and guanine) by HPLC as described by Balcells et al. (1992), using allopurinol as internal standard.

Methane was analyzed with a gas chromatograph (Shimadzu GC 14B; Shimadzu Corporation, Kyoto, Japan) equipped with a flame-ionization detector and a column packed with Carboxen 1000 (Supelco, Madrid, Spain). The carrier gas was He and peaks were identified by comparison with a standard of known composition. The volume of gas produced (milliliters) was corrected for standard conditions $\left(10^{5} \mathrm{~Pa}, 298 \mathrm{~K}\right)$, and the amount of $\mathrm{CH}_{4}$ produced (micromoles) was calculated by multiplying the gas produced (micromoles) by the concentration of $\mathrm{CH}_{4}$ in the analyzed sample.

\section{Statistical Analyses}

All statistical analyses were conducted using SAS (version 8.1; SAS Institute, Inc., Cary, NC). The computations of the in vitro batch fermentation and the gas production trials were performed using the PROC MIXED procedure of SAS, with run considered a random effect. Treatment results are reported as least 
Table 1. Effect of different doses of garlic oil, diallyl sulfide, diallyl disulfide, allyl mercaptan, and allicin on a 24 -h in vitro batch culture rumen microbial fermentation trial.

\begin{tabular}{|c|c|c|c|c|c|c|}
\hline & \multicolumn{5}{|c|}{ Concentration, mg/L } & \multirow[b]{2}{*}{$\mathrm{SEM}^{1}$} \\
\hline & 0 & 3 & 30 & 300 & 3000 & \\
\hline \multicolumn{7}{|l|}{ Garlic oil } \\
\hline $\begin{array}{l}\text { Total VFA, } \mathrm{m} M, \mathrm{Q}^{2} \\
\text { Individual, } \mathrm{mol} / 100 \mathrm{~mol}\end{array}$ & 123.1 & 127.9 & 124.9 & $110.1^{*}$ & $92.0 *$ & 4.95 \\
\hline Acetate, $\mathrm{C}^{2}$ & 65.3 & 64.5 & $62.9^{*}$ & $58.5^{*}$ & $59.9 *$ & 0.27 \\
\hline Propionate, C & 17.3 & 17.7 & $18.3^{*}$ & $20.1^{*}$ & $16.4^{*}$ & 0.20 \\
\hline Butyrate, C & 13.1 & 13.4 & $14.3^{*}$ & $16.9 *$ & $19.2 *$ & 0.33 \\
\hline Branched-chain VFA, $\mathrm{L}^{2}$ & 2.9 & 2.9 & 3.0 & 2.9 & $2.5^{*}$ & 0.06 \\
\hline $\mathrm{pH}, \mathrm{Q}$ & 6.2 & 6.1 & 6.2 & $6.4^{*}$ & $6.6^{*}$ & 0.14 \\
\hline $\mathrm{NH}_{3} \mathrm{~N}, \mathrm{mg} / \mathrm{dL}, \mathrm{C}$ & 21.9 & 23.7 & $24.7^{*}$ & 23.1 & 20.9 & 0.71 \\
\hline \multicolumn{7}{|l|}{ Diallyl sulfide } \\
\hline Total VFA, $\mathrm{m} M, \mathrm{~L}$ & 123.1 & $130.8^{*}$ & $130.5^{*}$ & 128.9 & $80.9 *$ & 3.20 \\
\hline \multicolumn{7}{|l|}{ Individual, mol/100 mol } \\
\hline Acetate, Q & 65.3 & 65.5 & 65.7 & $64.3 \dagger$ & 65.8 & 0.29 \\
\hline Propionate, L & 17.3 & 17.1 & 17.2 & 17.2 & $15.0^{*}$ & 0.23 \\
\hline Butyrate, Q & 13.1 & 13.0 & 12.9 & $14.1^{*}$ & $15.5^{*}$ & 0.42 \\
\hline Branched-chain VFA, Q & 2.9 & 2.9 & 2.8 & 3.0 & $2.5^{*}$ & 0.05 \\
\hline $\mathrm{pH}, \mathrm{L}$ & 6.2 & $6.1^{*}$ & $6.2^{*}$ & 6.2 & $6.6^{*}$ & 0.15 \\
\hline $\mathrm{NH}_{3} \mathrm{~N}, \mathrm{mg} / \mathrm{dL}, \mathrm{Q}$ & 21.9 & $24.7^{*}$ & $24.4^{*}$ & $25.0^{*}$ & $17.3^{*}$ & 0.76 \\
\hline \multicolumn{7}{|l|}{ Diallyl disulfide } \\
\hline Total VFA, $\mathrm{m} M, \mathrm{Q}$ & 123.1 & 127.5 & 128.3 & $114.0^{*}$ & $78.6^{*}$ & 2.44 \\
\hline \multicolumn{7}{|l|}{ Individual, $\mathrm{mol} / 100 \mathrm{~mol}$} \\
\hline Acetate, Q & 65.3 & 65.1 & $64.2^{*}$ & $58.4^{*}$ & $66.7^{*}$ & 0.33 \\
\hline Propionate, Q & 17.3 & 17.4 & $17.8^{*}$ & $20.3^{*}$ & $16.6^{*}$ & 0.31 \\
\hline Butyrate, Q & 13.1 & 13.2 & 13.6 & $16.6^{*}$ & 13.0 & 0.37 \\
\hline Branched-chain VFA, Q & 2.9 & 2.9 & 2.9 & 3.0 & $2.5^{*}$ & 0.05 \\
\hline $\mathrm{pH}, \mathrm{Q}$ & 6.2 & $6.1^{*}$ & 6.2 & $6.4^{*}$ & $6.6^{*}$ & 0.16 \\
\hline $\mathrm{NH}_{3} \mathrm{~N}, \mathrm{mg} / \mathrm{dL}, \mathrm{C}$ & 21.9 & $23.7^{*}$ & $24.4^{*}$ & $23.2^{*}$ & $13.5^{*}$ & 0.48 \\
\hline \multicolumn{7}{|l|}{ Allyl mercaptan } \\
\hline Total VFA, mM, Q & 123.1 & 127.9 & 128.0 & $116.2^{*}$ & $96.2^{*}$ & 1.99 \\
\hline \multicolumn{7}{|l|}{ Individual, $\mathrm{mol} / 100 \mathrm{~mol}$} \\
\hline Acetate, Q & 65.3 & 65.4 & 65.2 & $59.4^{*}$ & $56.2^{*}$ & 0.50 \\
\hline Propionate, Q & 17.3 & 17.2 & 17.4 & $19.9 *$ & $18.0 *$ & 0.31 \\
\hline Butyrate, Q & 13.1 & 13.1 & 13.2 & $16.0^{*}$ & $22.2^{*}$ & 0.70 \\
\hline Branched-chain VFA, Q & 2.9 & 2.8 & 2.8 & 3.0 & $2.2^{*}$ & 0.07 \\
\hline $\mathrm{pH}, \mathrm{L}$ & 6.2 & 6.2 & $6.2^{*}$ & $6.4^{*}$ & $6.6^{*}$ & 0.16 \\
\hline $\mathrm{NH}_{3} \mathrm{~N}, \mathrm{mg} / \mathrm{dL}, \mathrm{L}$ & 21.9 & $23.5 \dagger$ & $23.8^{*}$ & $23.7^{*}$ & 21.1 & 0.43 \\
\hline \multicolumn{7}{|l|}{ Allicin } \\
\hline Total VFA, mM & 123.1 & 127.3 & 126.4 & 124.8 & 122.5 & 1.33 \\
\hline \multicolumn{7}{|l|}{ Individual, mol/100 mol } \\
\hline Acetate & 65.3 & 65.5 & 65.3 & 65.1 & 64.8 & 0.55 \\
\hline Propionate & 17.3 & 17.2 & 17.4 & 17.5 & $17.7^{*}$ & 0.34 \\
\hline Butyrate & 13.1 & 12.9 & 13.1 & 13.2 & 13.3 & 0.56 \\
\hline Branched-chain VFA, L & 2.9 & 2.9 & 2.8 & 2.8 & $2.7^{*}$ & 0.03 \\
\hline $\mathrm{pH}$ & 6.2 & 6.2 & 6.2 & $6.2^{*}$ & $6.2^{*}$ & 0.18 \\
\hline $\mathrm{NH}_{3} \mathrm{~N}, \mathrm{mg} / \mathrm{dL}, \mathrm{C}$ & 21.9 & 22.8 & $23.4^{\dagger}$ & 22.6 & 21.6 & 0.41 \\
\hline
\end{tabular}

${ }^{1} \mathrm{SEM}=$ Standard error of the mean.

${ }^{2} \mathrm{~L}, \mathrm{Q}, \mathrm{C}=$ Linear, quadratic and cubic effects, respectively $(P<0.05)$.

*Means within a row differ from control $(P<0.05)$.

$\dagger$ Means within a row differ from control $(P<0.10)$.

squares means. In the batch fermentation trial, differences between treatments and control were declared significant at $P<0.05$ using the Dunnett comparison test. In the gas production trial, differences between treatments were declared significant at $P<0.05$ using the Tukey multiple comparison test. Nonorthogonal polynomial contrasts were used to test for linear, quadratic, and cubic trends in the batch fermentation trial.
In the continuous culture trial, results for the determination of VFA and ammonia $\mathrm{N}$ concentrations (during the adaptation days) and $\mathrm{N}$ fractions (LPep, SPep+AA N, and ammonia N; during the sampling days) were analyzed using the PROC MIXED for repeated measures (Littell et al., 1998). The model accounted for the effects of treatments and days (for VFA and ammonia $\mathrm{N}$ ) or hours (for the protein fractions in $\mathrm{d}$ 
6,7 , and 8 ) of sampling, and the interaction of treatment with days or treatment with hours. The period was considered a random effect. The VFA concentrations and $\mathrm{N}$ fractions were subjected to 3 covariance structures: compound symmetric, autoregressive order one, and unstructured covariance. The covariance structure that yielded the largest Schwarz's Bayesian criterion was considered the most desirable analysis, and the least squares means for treatments are reported. Differences in average between treatments were declared at $P<0.05$ using the Tukey multiple comparison test (Tukey, 1953). For comparisons in $\mathrm{N}$ fractions between treatments at each hour, and between $0 \mathrm{~h}$ and 2,4 , and $6 \mathrm{~h}$ within treatments, the Bonferroni comparison test was used and differences were declared at $P<0.05$.

Results of DM, OM, NDF, ADF, and CP digestibilities, VFA, ammonia $\mathrm{N}$ concentrations, and flows of total $\mathrm{N}$, NAN, bacterial $\mathrm{N}$, and dietary $\mathrm{N}$ were analyzed as a randomized block design. Main effects and its interactions were determined with the ANOVA using the PROC MIXED procedure of SAS. Differences between treatments were declared at $P<0.05$ using the Tukey multiple comparison test, and least squares means for treatments are shown.

\section{RESULTS}

\section{In Vitro Batch Fermentation Trial}

Relative to the control, addition of high levels (3000 $\mathrm{mg} / \mathrm{L}$ ) of all compounds, except ALL, resulted in an increase in $\mathrm{pH}$, and a decrease in total VFA concentration and molar proportion of branched-chain VFA (Table 1). At $3000 \mathrm{mg} / \mathrm{L}$, ALL also increased $\mathrm{pH}$ and decreased branched-chain VFA compared with control, but had no effects on total VFA concentration. At 300 $\mathrm{mg} / \mathrm{L}, \mathrm{GAR}, \mathrm{DAD}$, and ALM increased $\mathrm{pH}$ and decreased total VFA concentration. In contrast, at 3 and $30 \mathrm{mg} / \mathrm{L}$, DAS decreased $\mathrm{pH}$ and increased total VFA concentration, whereas at $3 \mathrm{mg} / \mathrm{L}, \mathrm{DAD}$ decreased $\mathrm{pH}$ compared with control.

The GAR resulted in a cubic effect in the proportion of acetate being lower at 30,300 , and $3000 \mathrm{mg} / \mathrm{L}$ compared with control. The molar proportion of acetate changed quadratically in DAS (lowest at $300 \mathrm{mg} / \mathrm{L}$ ), DAD (lowest $300 \mathrm{mg} / \mathrm{L}$ and highest at $3000 \mathrm{mg} / \mathrm{L}$ ), and ALM (lowest $3000 \mathrm{mg} / \mathrm{L}$ ). The GAR resulted in a cubic effect in the proportion of propionate being higher at 30 and 300 $\mathrm{mg} / \mathrm{L}$, and lower at $3000 \mathrm{mg} / \mathrm{L}$, compared with control. The proportion of propionate changed quadratically in DAD (highest at $300 \mathrm{mg} / \mathrm{L}$ and lowest at $3000 \mathrm{mg} / \mathrm{L}$ ) and ALM (highest at $300 \mathrm{mg} / \mathrm{L}$ ). Increasing levels of DAS resulted in a linear $(P<0.05)$ decrease in the proportion of propionate. The GAR resulted in a cubic effect in the proportion of butyrate being higher at 30 ,
300 , and $3000 \mathrm{mg} / \mathrm{L}$ compared with control. The proportion of butyrate changed quadratically in DAS (highest at $3000 \mathrm{mg} / \mathrm{L}$ ), DAD (highest at $300 \mathrm{mg} / \mathrm{L}$ ), and ALM (highest at $3000 \mathrm{mg} / \mathrm{L}$ ).

The ALM resulted in a linear decrease in the ammonia $\mathrm{N}$ concentration, whereas GAR (highest at $30 \mathrm{mg} /$ $\mathrm{L}$ ), DAD (highest at $30 \mathrm{mg} / \mathrm{L}$ and lowest at $3000 \mathrm{mg} /$ $\mathrm{L}$ ), and ALL (highest at $30 \mathrm{mg} / \mathrm{L}$ ) resulted in a cubic effect. The ammonia $\mathrm{N}$ concentration changed quadratically in DAS (highest at $300 \mathrm{mg} / \mathrm{L}$ and lowest at 3000 $\mathrm{mg} / \mathrm{L})$.

\section{In Vitro Continuous Culture Trial}

Total and individual VFA, and ammonia $\mathrm{N}$ concentrations $2 \mathrm{~h}$ after the morning feeding decreased in the first $2 \mathrm{~d}$ of fermentation in all treatments, and remained constant thereafter (data not shown) indicating that 2 $\mathrm{d}$ was a sufficient period for the adaptation of rumen microflora to the fermentation conditions and to the presence of the feed additives.

During sampling days, total VFA concentration was similar in all treatments except in ALM300, which was lower compared with control (Table 2). All treatments resulted in lower molar proportion of acetate and lower acetate to propionate ratio compared with control. The GAR300 and ALM300 increased the molar proportions of propionate, butyrate, and valerate compared with control. The DAD300 also had higher molar proportions of butyrate and valerate, but had no effect on propionate compared with control. No significant effects of the additives on the proportion of branched-chain VFA were observed compared with the control. The true DM, OM, $\mathrm{NDF}$, and ADF digestibilities were not affected by treatments compared with control (Table 2).

Concentration of LPep N (mg/100 mL) in control remained constant between feedings, and there were no treatment effects on the average LPep $\mathrm{N}$ concentration (Table 3). The SPep+AA N concentration $(\mathrm{mg} / 100 \mathrm{~mL})$ in control increased from 1.3 at $0 \mathrm{~h}$ to 4.3 and 3.5 at 2 and $4 \mathrm{~h}$, respectively, after feeding, and returned to prefeeding levels at $6 \mathrm{~h}$ (Table 3 ). The average SPep+AA $\mathrm{N}$ concentration throughout all hours between feedings was similar in all treatments, although DAD300 tended $(P=0.07)$ to increase it compared with the control. The ammonia $\mathrm{N}$ concentration $(\mathrm{mg} / 100 \mathrm{~mL})$ in the control increased from 10.6 at $0 \mathrm{~h}$ to 12.9 at $2 \mathrm{~h}$ after feeding, and returned to prefeeding levels at $4 \mathrm{~h}$ (Table 3). No significant effects of treatments on average ammonia $\mathrm{N}$ concentration were observed, although tended $(P=$ 0.08 ) to be higher in ALM300 compared with the control (Table 3).

There were no treatment effects on effluent ammonia $\mathrm{N}$ concentration, dietary or bacterial $\mathrm{N}$ flows, protein 
Table 2. Effects of garlic oil, diallyl disulfide, and allyl mercaptan on VFA concentrations, DM, OM, NDF, and $\mathrm{ADF}$ digestibilities in a continuous culture rumen microbial fermentation trial.

\begin{tabular}{lccccccc}
\hline & \multicolumn{7}{c}{ Treatments $^{1}$} \\
\cline { 2 - 5 } Item & Control & GAR300 & DAD30 & DAD300 & ALM30 & ALM300 & SEM $^{2}$ \\
\hline True digestibility & & & & & & \\
DM, \% & 59.8 & 55.3 & 58.9 & 55.1 & 56.7 & 56.0 & 2.57 \\
OM, \% & 55.6 & 51.4 & 55.6 & 51.9 & 52.8 & 52.5 & 2.17 \\
Fiber digestibility & & & & & & & \\
NDF, \% & 36.7 & 33.5 & 35.7 & 34.9 & 35.8 & 37.4 & 1.83 \\
ADF, \% & 36.0 & 29.6 & 32.9 & 30.9 & 32.7 & 33.0 & 1.82 \\
Total VFA, mM & $110.4^{\mathrm{a}}$ & $100.9^{\mathrm{ab}}$ & $106.2^{\mathrm{ab}}$ & $100.7^{\mathrm{ab}}$ & $104.2^{\mathrm{ab}}$ & $96.3^{\mathrm{b}}$ & 3.82 \\
Individual, mol/100 mol & & & & & & & \\
Acetate & $62.7^{\mathrm{a}}$ & $46.1^{\mathrm{c}}$ & $55.0^{\mathrm{b}}$ & $49.2^{\mathrm{c}}$ & $57.5^{\mathrm{b}}$ & $48.5^{\mathrm{c}}$ & 1.24 \\
Propionate & $20.5^{\mathrm{c}}$ & $32.0^{\mathrm{a}}$ & $23.1^{\mathrm{bc}}$ & $23.9^{\mathrm{bc}}$ & $23.9^{\mathrm{bc}}$ & $26.0^{\mathrm{b}}$ & 1.33 \\
Butyrate & $11.6^{\mathrm{c}}$ & $15.6^{\mathrm{b}}$ & $14.7^{\mathrm{bc}}$ & $19.9^{\mathrm{a}}$ & $11.6^{\mathrm{c}}$ & $18.1^{\mathrm{ab}}$ & 0.91 \\
Isobutyrate & 0.5 & 0.6 & 0.5 & 0.6 & 0.5 & 0.7 & 0.05 \\
Isovalerate & $2.4^{\mathrm{ab}}$ & $0.9^{\mathrm{b}}$ & $3.7^{\mathrm{a}}$ & $1.2^{\mathrm{b}}$ & $3.4^{\mathrm{a}}$ & $1.6^{\mathrm{b}}$ & 0.37 \\
Valerate & $2.1^{\mathrm{b}}$ & $4.7^{\mathrm{a}}$ & $2.8^{\mathrm{b}}$ & $4.9^{\mathrm{a}}$ & $2.8^{\mathrm{b}}$ & $3.9^{\mathrm{a}}$ & 0.33 \\
BCVFA & $2.9^{\mathrm{ab}}$ & $1.5^{\mathrm{b}}$ & $4.2^{\mathrm{a}}$ & $1.9^{\mathrm{b}}$ & $3.9^{\mathrm{a}}$ & $2.3^{\mathrm{b}}$ & 0.40 \\
C2:C3 & $3.2^{\mathrm{a}}$ & $1.4^{\mathrm{c}}$ & $2.4^{\mathrm{b}}$ & $2.0^{\mathrm{b}}$ & $2.5^{\mathrm{b}}$ & $1.9^{\mathrm{b}}$ & 0.18 \\
\hline ab, & & & & &
\end{tabular}

a,b,c Means within a row with different superscript differ $(P<0.05)$.

${ }^{1}$ Treatments: GAR300 = $312 \mathrm{mg} / \mathrm{L}$ Allium sativa (garlic oil); DAD30 = $31.2 \mathrm{mg} / \mathrm{L}$ diallyl disulfide; DAD300 = $312 \mathrm{mg} / \mathrm{L}$ diallyl disulfide; ALM30 = $31.2 \mathrm{mg} / \mathrm{L}$ allyl mercaptan; ALM300 = $312 \mathrm{mg} / \mathrm{L}$ allyl mercaptan.

${ }^{2} \mathrm{SEM}=$ Standard error of the mean.

${ }^{3}$ Branched-chain VFA, includes isobutyrate and isovalerate.

${ }^{4}$ Acetate to propionate ratio.

Table 3. Effect of garlic oil, diallyl disulfide, and allyl mercaptan on nitrogen fraction concentrations (mg/ $100 \mathrm{~mL}$ ) during the 6 -h postfeeding cycle in the continuous culture rumen microbial fermentation trial.

\begin{tabular}{|c|c|c|c|c|c|c|c|}
\hline \multirow[b]{2}{*}{$\mathrm{N}$ fraction/h } & \multicolumn{6}{|c|}{ Treatments $^{1}$} & \multirow[b]{2}{*}{$\mathrm{SEM}^{2}$} \\
\hline & Control & GAR300 & DAD30 & DAD300 & ALM30 & ALM300 & \\
\hline \multicolumn{8}{|l|}{$\mathrm{LPep}^{3} \mathrm{~N}$} \\
\hline 0 & 3.4 & 4.6 & 3.6 & 4.1 & 4.9 & 4.9 & 1.05 \\
\hline 2 & 3.9 & 4.9 & 3.7 & 3.5 & 3.7 & 4.6 & 1.05 \\
\hline 4 & 4.2 & 5.2 & 3.6 & 3.5 & 3.7 & 4.0 & 1.05 \\
\hline 6 & 3.0 & 5.9 & 2.8 & 3.3 & 4.4 & 3.6 & 1.05 \\
\hline Average & 3.6 & 5.1 & 3.4 & 3.6 & 4.2 & 4.2 & 0.91 \\
\hline \multicolumn{8}{|l|}{$\mathrm{SPep}+\mathrm{AA}^{4} \mathrm{~N}$} \\
\hline 0 & 1.3 & 1.6 & 2.2 & 2.4 & 0.8 & 2.1 & 0.60 \\
\hline 2 & $4.3^{z, a b}$ & $5.5^{\mathrm{z}, \mathrm{ab}}$ & $5.7^{\mathrm{z}, \mathrm{ab}}$ & $6.4^{\mathrm{za}, \mathrm{a}}$ & $4.0^{\mathrm{z}, \mathrm{b}}$ & $5.3^{z, a b}$ & 0.60 \\
\hline 4 & $3.5^{z}$ & $3.9^{\mathrm{z}}$ & $4.7^{\mathrm{z}}$ & $5.3^{\mathrm{z}}$ & $3.7^{\mathrm{z}}$ & $3.9^{\mathrm{z}}$ & 0.60 \\
\hline 6 & $2.7^{\mathrm{ab}}$ & $2.3^{\mathrm{ab}}$ & $3.7^{\mathrm{ab}}$ & $4.1^{\mathrm{a}}$ & $1.8^{\mathrm{b}}$ & $3.0^{\mathrm{ab}}$ & 0.60 \\
\hline Average & $2.9^{\mathrm{ab}}$ & $3.4^{\mathrm{ab}}$ & $4.1^{\mathrm{ab}}$ & $4.6^{\mathrm{a}}$ & $2.6^{\mathrm{b}}$ & $3.6^{\mathrm{ab}}$ & 0.50 \\
\hline \multicolumn{8}{|l|}{ Ammonia $\mathrm{N}$} \\
\hline 0 & $10.6^{\mathrm{ab}}$ & $11.5^{\mathrm{ab}}$ & $7.8^{\mathrm{b}}$ & $12.0^{\mathrm{ab}}$ & $8.5^{b}$ & $15.7^{\mathrm{a}}$ & 1.45 \\
\hline 2 & $12.9^{\mathrm{z}}$ & $14.8^{\mathrm{z}, \mathrm{ab}}$ & $9.4^{\mathrm{z}, \mathrm{b}}$ & $12.4^{\mathrm{ab}}$ & $10.7^{\mathrm{z}, \mathrm{b}}$ & $17.9^{\mathrm{z}, \mathrm{a}}$ & 1.45 \\
\hline 4 & $9.6^{\mathrm{ab}}$ & $10.4^{\mathrm{ab}}$ & $5.7^{\mathrm{z}, \mathrm{b}}$ & $9.8^{\mathrm{z}, \mathrm{ab}}$ & $7.5^{\mathrm{b}}$ & $14.2^{\mathrm{a}}$ & 1.45 \\
\hline 6 & $8.8^{\mathrm{ab}}$ & $9.1^{\mathrm{z}, \mathrm{ab}}$ & $5.5^{\mathrm{b}}$ & $9.9^{\mathrm{ab}}$ & $7.2^{\mathrm{b}}$ & $13.7^{\mathrm{a}}$ & 1.45 \\
\hline Average & $10.5^{\mathrm{ab}}$ & $11.5^{\mathrm{ab}}$ & $7.1^{\mathrm{b}}$ & $11.0^{\mathrm{ab}}$ & $8.5^{\mathrm{b}}$ & $15.4^{\mathrm{a}}$ & 1.39 \\
\hline
\end{tabular}

${ }^{\mathrm{a}, \mathrm{b}}$ Means within a row with different superscript differ $(P<0.05)$.

${ }^{\mathrm{z}}$ Means within a column significantly different from $0 \mathrm{~h}(P<0.05)$.

${ }^{1}$ Treatments: GAR300 = $312 \mathrm{mg} / \mathrm{L}$ Allium sativa (garlic oil); DAD30 = $31.2 \mathrm{mg} / \mathrm{L}$ diallyl disulfide; DAD300 = $312 \mathrm{mg} / \mathrm{L}$ diallyl disulfide; ALM30 = $31.2 \mathrm{mg} / \mathrm{L}$ allyl mercaptan; ALM300 = $312 \mathrm{mg} / \mathrm{L}$ allyl mercaptan.

${ }^{2} \mathrm{SEM}=$ Standard error of the mean.

${ }^{3} \mathrm{LPep}=$ Large peptide.

${ }^{4} \mathrm{SPep}+\mathrm{AA}=$ Small peptide plus amino acid. 
Table 4. Effect of garlic oil, diallyl disulfide, and allyl mercaptan on average nitrogen concentrations in a continuous culture rumen microbial fermentation trial.

\begin{tabular}{lccccccc}
\hline & \multicolumn{7}{c}{ Treatments $^{1}$} \\
\cline { 2 - 6 } & Control & GAR300 & DAD30 & DAD300 & ALM30 & ALM300 & SEM $^{2}$ \\
\hline N-NH3, mg/100 mL & $5.7^{\mathrm{ab}}$ & $6.8^{\mathrm{ab}}$ & $3.8^{\mathrm{b}}$ & $6.7^{\mathrm{ab}}$ & $5.4^{\mathrm{ab}}$ & $9.2^{\mathrm{a}}$ & 1.24 \\
N flow, g/d & 3.4 & 3.4 & 3.5 & 3.4 & 3.4 & 3.4 & 0.04 \\
Total & $0.2^{\mathrm{ab}}$ & $0.2^{\mathrm{ab}}$ & $0.1^{\mathrm{b}}$ & $0.2^{\mathrm{ab}}$ & $0.1^{\mathrm{ab}}$ & $0.3^{\mathrm{a}}$ & 0.04 \\
Ammonia & $3.2^{\mathrm{ab}}$ & $3.2^{\mathrm{ab}}$ & $3.3^{\mathrm{a}}$ & $3.2^{\mathrm{ab}}$ & $3.3^{\mathrm{ab}}$ & $3.1^{\mathrm{b}}$ & 0.05 \\
Nonammonia & 1.6 & 1.8 & 1.7 & 1.7 & 1.6 & 1.6 & 0.15 \\
Dietary & 1.6 & 1.4 & 1.7 & 1.4 & 1.6 & 1.5 & 0.15 \\
Bacterial & 40.6 & 33.2 & 39.8 & 34.2 & 40.8 & 42.2 & 5.89 \\
Protein degradation, \% & 31.4 & 29.5 & 32.9 & 28.9 & 33.4 & 31.9 & 1.95 \\
\hline EMPS, ${ }^{3}$ g/kg of TOMD &
\end{tabular}

\footnotetext{
${ }^{\mathrm{a}, \mathrm{b}}$ Means within a row with different superscript differ $(P<0.05)$.

${ }^{1}$ Treatments: GAR300 = $312 \mathrm{mg} / \mathrm{L}$ Allium sativa (garlic oil); DAD $30=31.2 \mathrm{mg} / \mathrm{L}$ diallyl disulfide; DAD300 = $312 \mathrm{mg} / \mathrm{L}$ diallyl disulfide; ALM30 = $31.2 \mathrm{mg} / \mathrm{L}$ allyl mercaptan; ALM300 = $312 \mathrm{mg} / \mathrm{L}$ allyl mercaptan.

${ }^{2} \mathrm{SEM}=$ Standard error of the mean.

${ }^{3}$ EMPS $=$ Efficiency of microbial protein synthesis.

${ }^{4} \mathrm{TOMD}=$ True OM digestibility.
}

degradation, or efficiency of microbial protein synthesis compared with the control (Table 4).

\section{In Vitro Gas Production Trial}

Final $\mathrm{pH}$ was not affected by treatment (average of 6.6; Table 5). The apparent disappearance of DM, NDF, and $\mathrm{ADF}$ digestibilities, gas and $\mathrm{CH}_{4}$ production, and the ratio $\mathrm{CH}_{4}$ :VFA decreased in GAR300, DAD300, and MON compared with the control. Total VFA concentration was lower in GAR300, DAD300, and ALM300 com- pared with the control. The molar proportion of acetate decreased and the molar proportion of propionate increased in GAR300, DAD300, and MON compared with the control. The molar proportion of butyrate increased in GAR300, decreased in MON, and had no effect in DAD300 compared with the control. The ALM300 resulted in a decrease in the molar proportion of acetate and an increase in the molar proportion of butyrate compared with the control, but had no effect on propionate. The DAD300 also tended $(P=0.07)$ to increase the concentration of ammonia $\mathrm{N}$, whereas MON de-

Table 5. Effect of garlic oil, diallyl disulfide, allyl mercaptan, monensin, and lovastatin on a 17-h in vitro batch culture rumen microbial fermentation trial.

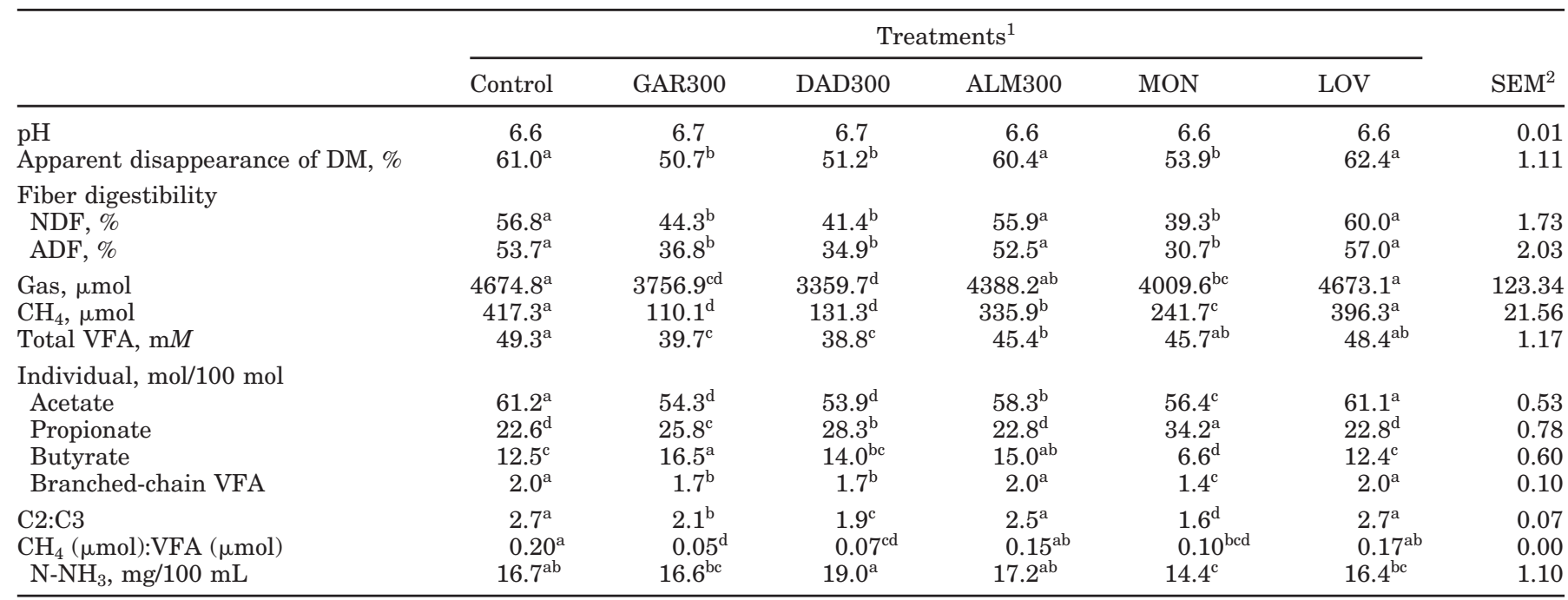

${ }^{\mathrm{a}-\mathrm{d}}$ Means within a row with different superscript differ $(P<0.05)$.

${ }^{1}$ Treatments: GAR300 $=300 \mathrm{mg} / \mathrm{L}$ Allium sativa (garlic oil); DAD300 = $300 \mathrm{mg} / \mathrm{L}$ diallyl disulfide; ALM300 = $300 \mathrm{mg} / \mathrm{L}$ allyl mercaptan; $\mathrm{MON}=12.5 \mathrm{mg} / \mathrm{L}$ monensin; $\mathrm{LOV}=5 \mathrm{mg} / \mathrm{L}$ lovastatin.

${ }^{2} \mathrm{SEM}=$ Standard error of the mean. 
creased it compared with the control. The LOV treatment had no effect on rumen microbial fermentation compared with the control.

\section{DISCUSSION}

In the batch fermentation trial, high concentrations (300 and $3000 \mathrm{mg} / \mathrm{L}$ ) of all compounds (except ALL) resulted in detrimental effects on rumen microbial fermentation (decrease in total VFA concentration), which confirms their antimicrobial activity (Reuter et al., 1996), and is in agreement with the effects observed in previous in vitro batch fermentation cultures with high doses of plant essential oils (Evans and Martin, 2000; Busquet et al., 2004). Garlic oil resulted in a decrease in the proportion of acetate and an increase in the proportions of propionate and butyrate, which agrees with observed results in previous batch and continuous culture studies (Busquet et al., 2004, 2005). Diallyl disulfide and ALM also resulted in similar effects on the proportions of individual VFA to those observed with GAR. For this reason, DAD and ALM were selected for evaluation in the long term in vitro continuous culture and in the gas production trials. In contrast, ALL had no effect on rumen microbial fermentation. Since its discovery, the antimicrobial activity of garlic has been attributed to its organosulfur compounds, and particularly to allicin (Feldberg et al., 1988; Ankri and Mirelman, 1999). However, pure allicin is a volatile molecule that is poorly miscible in aqueous solutions and it is relatively reactive, being rapidly converted to other compounds under various conditions (Lawson, 1996). The stability of allicin is higher at low temperature and $\mathrm{pH}$, whereas it decreases as temperature and $\mathrm{pH}$ increase (Lawson, 1996). For this reason, Amagase et al. (2001) suggested that allicin might not contribute to the in vivo effects of garlic under physiological conditions. The conditions used in this experiment $\left(39^{\circ} \mathrm{C}\right.$ and $\mathrm{pH}$ 7.0) may have not been adequate for the stability of allicin and could have resulted in a loss of its activity in a relative short time, which could explain its lack of effects. Treatment with DAS resulted in small effects on rumen microbial fermentation. It has been suggested in numerous studies that the antimicrobial potency of allyl sulfides of garlic oil increases with each additional S atom (Reuter et al., 1996; O'Gara et al., 2000). This could explain why, in the present study, treatment with DAD (contains $2 \mathrm{~S}$ atoms) resulted in stronger effects compared with DAS (contains $1 \mathrm{~S}$ atom).

In contrast with the effects observed in the batch fermentation trial, in the continuous culture trial, a high concentration $(300 \mathrm{mg} / \mathrm{L})$ of all compounds except ALM did not result in a decrease in total VFA concentration. In addition, no effects of treatments were observed on DM, OM, and fiber digestibilities. These results suggest that, in general, additives were not detrimental for rumen microbial fermentation. The lack of detrimental effects in the long-term continuous culture study could be due to the longer adaptation time allowed to the rumen microflora, which may allow replacement of the inhibited microbial population by other resistant bacterial groups. Similar effects have been observed with monensin when comparing its short-term effects in vitro vs. long-term effects in vivo (Schelling, 1984). In the case of ALM, a high concentration $(300 \mathrm{mg} / \mathrm{L})$ in the continuous culture system resulted in a decrease in total VFA concentration without decreasing DM, OM, or fiber digestibilities. These results suggest that although ALM300 could have been detrimental on the production of VFA for some rumen bacteria, this effect did not affect the overall digestion of the feed.

In continuous culture, GAR300 and ALM300 resulted in a decrease in the molar proportion of acetate and an increase in the molar proportions of propionate and butyrate, similar to the effects observed in the batch fermentation trial. Treatment with DAD300 also increased the molar proportion of butyrate and decreased the proportion of acetate but had no effect on propionate. Similarly to the batch fermentation trial, the effects observed in the continuous culture trial with the compounds were dose-dependent, which agrees with the results observed in other studies when evaluating the antimicrobial activity of garlic oil and its compounds (Feldberg et al., 1988; O'Gara et al., 2000).

In the gas production trial, GAR300, DAD300, ALM300, and MON decreased total VFA concentration, and had lower disappearance of DM, and lower NDF and $\mathrm{ADF}$ digestibilities compared with the control. The GAR300 and DAD300 decreased the proportion of acetate and increased the proportions of propionate and butyrate, which agrees with the results observed in the batch fermentation trial. The ALM300 also increased the molar proportion of butyrate and decreased the proportion of acetate but had no effect on propionate. The results observed in the 3 in vitro trials on the proportions of individual VFA, suggest that the main effects of garlic oil and its compounds are focused on the decrease in acetate and the increase in butyrate proportions, whereas the effects on the proportion of propionate are more variable. This fact suggests that, in contrast with the mechanism of action of monensin (which specifically inhibits rumen gram-positive bacteria), the mechanism of action of garlic oil and its compounds is more related to a direct inhibition of methanogenesis. This hypothesis is supported by the observed higher inhibition of GAR300 and DAD300 on methane production (73.6 and $68.5 \%$, respectively) when compared with monensin $(42.0 \%)$. It is also interesting to note that in 
the gas production trial, GAR300 and DAD300 decreased the $\mathrm{CH}_{4}$ :VFA ratio, and to a higher extent than MON, although these differences were not significant. If these results were confirmed in vivo, the use of garlic oil and diallyl disulfide in ruminants fed a 50:50 forage:concentrate diet could increase the amount of energy obtained in the rumen per unit of fermented substrate.

In the previous in vitro continuous culture trial (Busquet et al., 2005), it was suggested that the mechanism of action of garlic oil on the inhibition of methanogenesis could be related to a direct inhibition of the rumen methanogenic archaea through an inhibition of the enzyme 3-hydroxy-3-methyl-glutaryl coenzyme A (HMGCoA) reductase by the organosulfur compounds found in garlic oil. Methanogens and other Archaea microorganisms have unique membrane lipids that contain glycerol joined by ether linkages to long-chain isoprenoid alcohols (De Rosa et al., 1986). The synthesis of the isoprenoid units in methanogenic archaea is catalyzed by HMG-CoA reductase in a similar way as for cholesterol synthesis in humans. Numerous studies have demonstrated the inhibitory effects of garlic-derived organosulfur compounds on cholesterol biosynthesis in hepatocytes by inhibition of the HMG-CoA reductase (Gebhardt and Beck, 1996; Cho and Xu, 2000), which could explain an inhibitory effect of garlic oil on methanogenic archaea. This hypothesis was supported by the findings of Miller and Wolin (2001) that demonstrated that lovastatin and mevastatin (which decrease cholesterol production in humans by inhibiting HMG-CoA reductase) have the potential to specifically inhibit rumen methanogenic archaea without affecting rumen bacteria due to their different membrane lipid composition. To try to confirm the hypothesis of the inhibitory effect of garlic oil on methanogenic archaea, lovastatin was included as positive control in the gas production trial to compare the effects of the antibiotic on rumen microbial fermentation patterns with the ones observed for garlic oil and its compounds under the same in vitro conditions. Although the concentration used for lovastatin $(5 \mathrm{mg} / \mathrm{L})$ in the gas production trial was higher than that recommended by Miller and Wolin $(4 \mathrm{mg} /$ L), lovastatin had no effects on methane production or other microbial fermentation parameters. The difference between the results observed by Miller and Wolin (2001) and the present trial with lovastatin could be due to the different in vitro systems used (pure cultures of rumen bacteria vs. mixed ruminal bacteria). The lack of effects of lovastatin in the present study does not allow us to confirm the hypothesis about the specific mechanism of action of garlic oil on rumen microbial fermentation, but neither can it be rejected. Further research will be required to finally confirm or reject this hypothesis.

In contrast with the effects of garlic oil and its compounds on energy metabolism, the effects on N metabolism in the 3 in vitro studies were more variable. Garlic oil had no effect on $\mathrm{N}$ metabolism in any of the 3 studies, with the exception of an increase in ammonia $\mathrm{N}$ concentration at $30 \mathrm{mg} / \mathrm{L}$ in the batch culture trial. In a previous in vitro continuous culture study (Busquet et al., 2005), $300 \mathrm{mg} / \mathrm{L}$ of garlic oil resulted in an increase in the SPep+AA N concentration. This effect was related to the observed decrease in the proportion of branchedchain VFA at the same dose, and the possible ability of garlic oil to inhibit deamination of branch-chained AA as a side effect of the inhibition of methanogenesis (Hino and Russell, 1985). In the present continuous culture trial, although GAR300 resulted in a lower proportion of branched-chain VFA compared with the control, this effect was not significant, which could explain the lack of a significant increase on the SPep+AA N concentration.

In the case of $\mathrm{DAD}$, an increase on the ammonia $\mathrm{N}$ concentration at $300 \mathrm{mg} / \mathrm{L}$ was observed in the batch fermentation and gas production trials. In contrast, in the continuous culture system, DAD300 tended to increase the SPep+AA N concentration but had no effect on ammonia $\mathrm{N}$ concentration or other rumen microbial $\mathrm{N}$ metabolism parameters, which makes it difficult to determine which process was stimulated or inhibited during protein degradation. In the continuous culture trial, $300 \mathrm{mg} / \mathrm{L}$ of ALM tended to increase the ammonia $\mathrm{N}$ concentration, similarly to the observed increase in the ammonia $\mathrm{N}$ concentration in the batch fermentation trial at the same concentration. However, ALM300 had no effects on ammonia $\mathrm{N}$ concentration in the gas production trial. It is interesting to note that, in general, the increases observed for ammonia $\mathrm{N}$ concentration in DAD and ALM coincide with studies in which stronger effects on VFA production were observed. These results suggest that the main effects of garlic oil and its compounds are focused on carbohydrate metabolism in the rumen, whereas the effects observed on $\mathrm{N}$ metabolism may be a consequence of the effects observed in the energy metabolism. On the other hand, LPep N concentration was not affected by treatments, which suggest that their effects, when they occur, may take place on the inhibition or stimulation of the peptidolysis or deamination processes rather than proteolysis.

In general, in all 3 studies, ALM resulted in similar effects to those observed with GAR, which suggests that this metabolite of garlic oil may conserve the effects of the main compounds. Allyl mercaptan is a common metabolite of allium-derived compounds as obtained after incubation of allicin and other allyl sulfides with 
fresh blood at $37^{\circ} \mathrm{C}$ or gastric fluids (Lawson, 1996). Because dietary garlic constituents are transformed into various metabolites, including allyl mercaptan, in the biological system, it is important to investigate the physiological role of those metabolites and their potential effects on rumen microbial fermentation.

Finally, GAR resulted in stronger effects when compared with the effects of each active compound individually, which agrees with results observed in previous studies (O'Gara et al., 2000; Ross et al., 2001). This suggests a possible synergistic effect between the compounds present in the oil. Alternatively, the effects observed in garlic oil could be due to the presence of other compounds not evaluated in the present study.

\section{CONCLUSIONS}

Garlic oil resulted in a decrease in the proportion of acetate and an increase in the proportions of propionate and butyrate. Diallyl disulfide and allyl mercaptan resulted in similar but milder effects than garlic oil, suggesting the existence of synergistic effects between the different compounds present in garlic oil. The decrease in methane production observed in garlic oil and its compounds confirms their ability to inhibit methanogenesis. The decrease in the $\mathrm{CH}_{4}$ :VFA ratio with garlic oil and diallyl disulfide suggests the potential of these compounds to improve rumen microbial fermentation by increasing the amount of energy obtained per unit of fermented substrate. In general, the effects of the additives on $\mathrm{N}$ metabolism were smaller and more variable, which suggest that they may be secondary to the effects observed in the energy metabolism.

\section{ACKNOWLEDGMENTS}

The authors would like to thank Pancosma S. A. for their financial support and technical assistance.

\section{REFERENCES}

Amagase, H., B. L. Petesch, H. Matsuura, S. Kasuga, and Y. Itakura. 2001. Intake of garlic and its bioactive components. Recent advances on the nutritional effects associated with the use of garlic as a supplement. J. Nutr. 131:955S-962S.

Ankri, S., and D. Mirelman. 1999. Antimicrobial properties of allicin from garlic. Microbes Infect. 2:125-129.

AOAC. 1990. Official Methods of Analysis. Vol I. 15th ed. Association of Official Analytical Chemists, Arlington, VA.

Balcells, J., J. A. Guada, J. M. Peiró, and D. S. Parker. 1992. Simultaneous determination of allantoin and oxypurines in biological fluids by high performance liquid chromatography. J. Chromatogr. 575:153-157.

Busquet, M., S. Calsamiglia, A. Ferret, and C. Kamel. 2004. Effects of different doses of plant extracts on rumen microbial fermentation. J. Dairy Sci. 87(Suppl. 1):213.
Busquet, M., S. Calsamiglia, A. Ferret, and C. Kamel. 2005. Effects of cinnamaldehyde, garlic oil on rumen microbial fermentation in a dual flow continuous culture. J. Dairy Sci. 88:2508-2516.

Chaney, A. L., and E. P. Marbach. 1962. Modified reagents for determination of urea and ammonia. Clin. Chem. 8:130-132.

Cho, S. B. H., and S. Xu. 2000. Effects of allyl mercaptan and various allium-derived compounds on cholesterol synthesis and secretion in Hep-G2 cells. Comp. Biochem. Physiol. C, Comp. Pharmacol. 126:195-201.

Davidson, P. M., and A. S. Naidu. 2000. Phyto-phenols. Pages 265293 in Natural Food Antimicrobial Systems. A. S. Naidu, ed. CRC Press, Boca Raton, FL.

De Rosa, M., A. Gambacorta, and A. Gliozzi. 1986. Structure, biosynthesis, and physicochemical properties of archaebacterial lipids. Microbiol. Rev. 50:70-80.

Evans, J. D., and S. A. Martin. 2000. Effects of thymol on ruminal microorganisms. Curr. Microbiol. 41:336-340.

FDA. 2004. Food and Drug Administration of the US, 21 CFR 184. Online. Available at: http://www.cfsan.fda.gov/eafus.html. Accessed Sep. 20, 2004.

Feldberg, R. S., S. C. Chang, A. N. Kotik, M. Nadler, Z. Neuwirth, D. C. Sundstrom, and N. H. Thompson. 1988. In vitro mechanism of inhibition of bacterial cell growth by allicin. Antimicrob. Agents Chemother. 32:1763-1768.

Gebhardt, R., and H. Beck. 1996. Differential inhibitory effects of garlic-derived organosulfur compounds on cholesterol biosynthesis in primary rat hepatocyte cultures. Lipids 31:1269-1276.

Goering, M. K., and P. J. Van Soest. 1970. Forage Fiber Analysis (Apparatus, Reagents, Procedures and Some Applications). Agric. Handbook No. 379. ARS-USDA, Washington, DC.

Hino, T., and J. B. Russell. 1985. Effect of reducing-equivalent disposal and NADH/NAD on deamination of amino acids by intact rumen microorganisms and their cell extracts. Appl. Environ. Microbiol. 50:1368-1374.

Hoover, W. H., B. A. Crooker, and C. J. Sniffen. 1976. Effects of differential solid-liquid removal rates on protozoa numbers in continuous culture of rumen contents. J. Anim. Sci. 43:528-534.

Jouany, J. P. 1982. Volatile fatty acids and alcohol determination in digestive contents, silage juice, bacterial cultures and anaerobic fermentor contents. Sci. Aliments 2:131-144.

Lawson, L. 1996. The composition and chemistry of garlic cloves and processed garlic. Pages 37-107 in Garlic. The Science and Therapeutic Application of Allium sativum L. and Related Species. H. P. Koch and L. D. Lawson, ed. Williams \& Wilkins, Baltimore, MD.

Licitra, G., T. M. Hernandez, and P. J. Van Soest. 1996. Standardization of procedures for nitrogen fractionation of ruminant feeds. Anim. Feed Sci. Technol. 57:347-358.

Littell, R. C., P. R. Henry, and C. B. Ammerman. 1998. Statistical analysis of repeated measures data using SAS procedures. J. Anim. Sci. 75:1216-1231.

Martin, S. A., and J. M. Macy. 1985. Effects of monensin, pyromellitic diimide and 2-bromoethanosulfonic acid on rumen fermentation in vitro. J. Anim. Sci. 60:544-550.

McDougall, E. I. 1948. Studies on rumiant saliva. 1. The composition and output of sheep's saliva. Biochem. J. 43:99-109.

Miller, T. L., and M. J. Wolin. 2001. Inhibition of growth of methaneproducing bacteria of the ruminant forestomach by hydroxymethylglutaryl-SCoA reductase inhibitors. J. Dairy Sci. 84:1445-1448.

Minato, H., and T. Suto. 1978. Technique for fractionation of bacteria in rumen microbial ecosystem. II. Attachment of bacteria isolated from bovine rumen to cellulose powder in vitro and elution of bacteria attached therefrom. J. Gen. Appl. Microbiol. 24:1-6.

NRC. 2001. Nutrient Requirements of Dairy Cattle. 7th rev. ed. Natl. Acad. Sci., Washington, DC.

O'Gara, E. A., D. J. Hill, and D. J. Maslin. 2000. Activities of garlic oil, garlic powder, and their diallyl constituents against Helicobacter pylori. Appl. Environ. Microbiol. 66:2269-2273.

Reuter, H. D., J. P. Koch, and L. Lawson. 1996. Therapeutic effects and applications of garlic and its preparations. Pages 135-212 
in Garlic. The Science and Therapeutic Application of Allium sativum L. and Related Species. H. P. Koch and L. D. Lawson ed. Williams \& Wilkins, Baltimore, MD.

Ross, Z. M., E. A. O'Gara, D. J. Hill, H. V. Sleightholme, and D. J. Maslin. 2001. Antimicrobial properties of garlic oil against human enteric bacteria: Evaluation of methodologies and comparisons with garlic oil sulfides and garlic powder. Appl. Environ. Microbiol. 67:475-480.

Schelling, G. T. 1984. Monensin mode of action in the rumen. J. Anim. Sci. 58:1518-1527.

Stern, M. D., and W. H. Hoover. 1990. The dual flow continuous culture system. Pages 17-32 in Proc. Continuous Culture Fermentors: Frustration or fermentation. Northwest ADSA-ASAS Regional Meeting, Chazy, NY.
Tukey, J. W. 1953. The problem of multiple comparison. Unpublished notes, Princeton University, NJ.

Van Soest, P. J., J. B. Robertson, and B. A. Lewis. 1991. Methods for dietary fiber, neutral fiber and nonstarch polysaccharides in relation to animal nutrition. J. Dairy Sci. 74:3588-3595.

Weller, R. A., and A. F. Pilgrim. 1974. Passage of protozoa and volatile fatty acids from the rumen of a sheep and from a continuous in vitro fermentation system. Br. J. Nutr. 32:341-351.

Whitehouse, N. L., V. M. Olson, C. G. Schwab, W. R. Chesbro, K. D. Cunningham, and K. D. Lycos. 1994. Improved techniques for dissociating particle-associated mixed ruminal microorganisms from ruminal digesta solids. J. Anim. Sci. 72:1335-1343.

Winter, K. A., R. R. Johnson, and B. A. Dehority. 1964. Metabolism of urea nitrogen by mixed cultures of rumen bacteria grown on cellulose. J. Anim. Sci. 23:793-797. 